\title{
有機合成化学は面白い！
}

布施新一郎

\section{Love Synthetic Organic Chemistry!}

Shinichiro Fuse

\section{はじめに}

筆者はこの企画の執筆依頼を頂いてすぐに，若手研究 者に向けてのお手本となりそうなメッセージを書くこと を断念した。何しろあまり真剣に将来を考えず「のほほ ん」と生きてきたところ, 幸運なことに周囲の様々な 方々の温かい支援や叱咤激励のおかげでPIになれたわ けであり，とても若手研究者のお手本となれる自信がな い。筆者のこれまでの歩みを伝えること自体が, 学生さ んに向けた気の利いたメッセージになれば願ってもない ことだが，果たしてそれがどれほど学生さんの役に立つ のかはなはだ疑問に感じ始めてこれも断念した。原点回 帰して執筆依頼状を見直したところ，「有機合成化学の 魅力を学生に伝えるには〜中略〜自分の言葉で有機合成 化学の『面白さ』を語ってもらう事が大切である」との文 が目に飛び込んできた。そうか，お手本とか役立つとか を考えず，「有機合成化学は面白い!」と感じている自分 を表現することなら筆者にもできそうだと思い，今キー ボードを叨いている。筆者は本当の意味での有機合成化 学の面白さが分かったのは 35 歳を過ぎた頃で, 今, こ れまでで最も有機合成化学が面白いと感じている。なぜ そう思うのか？ なぜ今が一番なのか？ 説明を試みた い。拙文を読む学生さんの一部でも「やっぱり有機合成 化学面白いよね」と思ってもらえたら，本当に嬉しい。

\section{有機合成化学は匠の技?}

1999 年, 東京工業大学工学部化学工学科応用化学 コースで，当時厳しく拘束時間が長いことで知られてい た高橋・山田研究室に筆者は所属した。高橋孝志先生 (現北里大学・横浜薬科大学教授) は, 他の先生方が研究 室紹介において，「触媒とは」，「錯体とは」というところ から話しだされる中, 一人だけ「日本経済の現状」から話 され始め, 興味を惹かれた。また，年末の講義では突 然, 聴講学生全員の目を閉じさせ,「お父さんお母さん が, どれほど頑張って皆さんを大学まで行かせてくれて いるか考えてみて下さい。決して勉学を途中で投げ出し てはなりません」「はい, 目を開けて下さい。このメッ
セージが私からのクリスマスプレゼントです」という一 幕もあり, 高橋先生の人間味あふれる雲囲気にも惹かれ 研究室に入った。

筆者の研究テーマは, 既に研究室で 10 年続いていた タキソールの全合成であり，何人もの先輩がタキソール のテーマで博士号を取得していた。修論発表のときにも 副査の故碇屋隆雄先生, 鈴木寛治先生に「もういい加減 あなたでこのテーマに決着をつけなさい」といった内容 のコメントを頂いた。一方で，おそらく当時世界的に見 ても有機化学分野の大学院生としては珍しい, 自動合成 ロボットを開発する機会を高橋先生に与えて頂き，ま た, 直接日々の研究をご指導頂いた土井隆行先生 (現東 北大学教授)には, 自由に研究に取り組ませて頂き, 様々な貴重な体験ができた。天然物全合成を目指す傍ら で反応開発にも取り組み, 初めて望みの反応が進行した のをTLC 解析で目の当たりにした際は本当に嬉しかっ た。ただし, 今振り返ってみると, 当時の（特に博士課 程での)筆者はまだ本当の有機合成化学の面白さは実感 できていなかったように思える。ロボットで有機合成を 変えられるかもしれないという期待感や夢はもっていた が，日々の研究では，匠が「仕事」に向かいあうときのよ うに, とにかく目標を達成すること, プロの仕事を完遂 することを目指していた(大変残念なことにその割にミ スが多かった)。これは, タキソールの合成経路自体, 筆者が一から組み上げたものではなく, 多くの先輩の苦 労の上に構築されたものであったこと, そして, タキ ソールの合成研究では保護基を一つ変えるだけで全く別 の化合物のような振る舞いになり，全合成を目指すと (筆者の実力では)おいそれとルートを変えられず，ルー 卜発想と検討, 成功のダイナミズムを味わいにくかった こともあるかもしれない。しかし, 博士課程 3 年時の春 の数カ月間, 毎日合計 2 時間 (15 分間 $\times 8$ セット)しか寝 ずに(化合物を壊す怖さで眠れなかった)実験を続け，な んとかゴールにたどり着けたことは, その後自分が有機 合成を生業とする研究者として生きる上での確かな自信 
になった。一方で,「研究は面白いとか面白くないとか そういうものではなく, やり遂げなければならない崇高 なもの」という感覚を抱いていた当時の頭のカタイ筆者 にとって，有機合成化学の本当の「面白さ」に気づくには もう少し時間がかかった。

\section{他の研究を経験してみる}

結局自分のことを知ろうと思ったら，他者を知り，そ の比較でしか自分をよく理解できないと感じることが多 いが, 有機合成化学の面白さを知ろうと思ったら, 逆説 的に他分野の研究を経験することが一番良いかもしれな い。筆者は留学先のハーバード大学化学・化学生物学科 の Daniel E. Khane 先生のもとで, モエノマイシンとい う抗生物質の類縁体合成と, 活性評価, 作用機序解明に 携わった。化合物の合成は本当に大変なのに, アッセイ は合成に比べればはるかに楽で(もちろんアッセイ系が 確立されていたためである), バンコマイシン耐性菌を 自分の合成した誘導体が殺しているのを直接観察するの はとても面白かった。またそれ以上に，過去の論文報告 とは異なる作用機序についての知見が得られ，「世界で 今, この事実は自分しか知らないんだろうなあ」という 優越感はたまらないものだった。一方で, 結果が再現し ないときや予想外の結果が得られた際には, 化学実験と 異なり，直接的にスペクトル測定などで原因を特定でき ないため, 調べても原因は「拉そらく」これ「だろう」とな る点, そもそも原因究明のプロセスに長時間を要する点 は生物系の研究の難しいところと実感した。

\section{マイクロフロー合成との出会い}

筆者がマイクロ流路を用いる研究を初めて知ったの は, 大学 4 年生 (1999 年)のときに初めて参加した日本 化学会の春季年会においてである。東京大学の北森武彦 先生が微小チャネルを用いるアッセイや反応に関連する 発表をされていて, 衝撃を受け, 高橋研に戻って, その 内容を紹介した。その後 10 年間は, 自分自身でフロー 合成を進める機会はなく日々を過ごしたが, 2008 年, 筆者の助教着任とほぼ入れ替わりで栄転された土井先生 のテーマの引き継ぎでフロー合成に携わることになっ た。たまたま初めて報告したフロー光反応の論文が意外 に多くの反響を呼んだという現金な理由から，さらにフ ロー合成に本腰を入れるようになった。この頃, 京都大 学の故吉田潤一先生のフラッシュケミストリーに衝撃を 受け, 自分達でもペプチドのフロー合成に真剣に取り組 み始めたが，検討パラメータが多すぎて研究をどう進め て良いかわからず，壁に直面した。幸運なことに新学術 領域研究の公募班員に入れていただたのを機に，直接 吉田先生のお部屋に担当学生と共に伺って永木愛一郎先 生にフロー反応実施上のコツを伝授頂いた。このとき に，どのパラメータは「検討しなくて良いか」を教わった ことで, 停滞していた研究がようやく進み始めた。
当時から今にまで至る研究目標は「ペプチドを, エピ メリ化を誘発せず高収率で合成すること」であり，まさ に, 課題解決志向の技術開発的研究に見える。開発対象 のアミド化は, 転位反応の開発で有名な T. Curtius 先 生が初のペプチド結合形成を報告してから実に 140 年も 経過しており長大な歴史をもつ。反応開発の素人である 筆者がアミド化開発にいまさら取り組むのは無謀な挑戦 ともいえる。これを可能にしてくれたのは一にも二にも フロー合成のおかげである。高活性で安価な反応剤を用 い, 反応時間を数秒に制御してアミド化を検討すると, 研究し尽くされたはずの反応でも「不思議な観察結果」が 次々と得られた。さらなる検証実験やスペクトル測定, 理論計算により, その謎が徐々に解けていく過程を学生 さんと一緒に体験した。先述の通り，ここでも「世界で 今，この事実は自分しか知らないんだろうなあ」という 優越感はやっぱりたまらないものだった。自分の科学者 としての幸せのツボを再認識するとともに, ある程度短 期間に，かなりの精度で謎解きができる有機化学はなん と素晴らしいのだろうと実感した。

とどのつまり，筆者らが開発している反応はいずれも 酸と塩基の作用をうまく利用しているだけともいえて原 理は至極単純である。反応自体は少なくとも数十年以上 前に報告されており, 新規な触媒も反応剂も使っていな い。しかしながら, 触媒として機能するアミン, プロト ンを捕捉するアミン, 求核剤となるアミン, 複数の求電 子剂, 溶媒, これらすべてが酸と相互作用するため, 実 際の反応制御はかなり複雑なものとなる。筆者はアミド 化反応開発を 10 年以上続けてきて, かなり色々なこと を学んだが，それでも未だに「この基質ならこの条件で 仕込めばよい」と一発で明確な答えを出すのは容易では ない。筆者は機械学習にも興味をもって研究での利用を 進めているが,「アミド化の制御を機械学習でなんとか するというのは, 少なくともしばらくの間は難しい なあ。有機化学は奥が深いなあ」と実感している。しか し，そう感じると幸せな気持ちにもなる。なにしろ，ま だまだ当分は化学者が有機合成化学の探求を楽しめるの たから。おまけにアミド化は有機合成化学において最も 重要な反応の一つでもあり，スケールアップが容易なフ ロー合成法と組み合わせていることもあり, 開発した手 法は産業応用への展開が期待される。科学的, 技術的, 両面での面白さを欲張りに味わえる点がフロー合成研究 の醍醐味である。

筆者は本当に恥ずかしながら，未だ自分自身でフロー 反応を仕込んだことがない。筆者の指導する学生さん は, 少なくともこの一点において, いつも筆者より上に いる。どんなにエラそうなこと言っても，自分でフロー 反応を仕込んだこともないセンセイよりも，日々フロー 反応を仕达んでいる学生さんの方が偉いに決まってい 
る。このような構図は, 筆者がフロー合成を真に楽しめ ている理由の一つとなっている気がしている。筆者は自 分自身が実験に向かう場合, 新発見を期待してワクワク しながら仕込むということはあまりない。先述の通り， 「匠の仕事」としてやるべき仕事をきっちりやるという考 えが先行するため，ときに有機合成を十分に楽しむ上で の障害にもなり得る。多くの先生方が発見にはちょっと した遊び心, 余裕が大切と仰っているが, その意味が何 となく分かるようになってきた。学生さんが頑張って集 めたフロー合成の結果を，「匠」としてではなく，客観的 に「研究者」として見聞きし，考察できるから，今，筆者 は有機合成化学を存分に楽しめているのかもしれない。

2015 年に東京工業大学資源化学研究所 (現化学生命化 学研究所)の中村浩之先生のグループに准教授として着 任し, 改めて広範な科学研究に触れる機会を与えて頂く とともに，自由にフロー合成を推進する機会も頂いた。 また, このときに先生やグループのメンバーに後押しを して頂き，理論計算や機械学習を駆使するテーマを開始 できた。鈍感な筆者は, 自分が一体何に対して科学者と しての幸せを感じるのか, 自分自身にとって, 有機合成 化学の真の面白さとは何なのかを見出すのに実に長い時 間を要した。こうして振り返ってみると, 恩師や先生 方, 学生さんとの出会いがあって, たどり着けたわけで あり, いくら感謝しても感謝しきれない。今後の出会い で, さらに私の有機合成化学の楽しみ方も変わってくる のだろうか。分析技術の進歩により, 将来生命科学分野 でも有機化学と同じょうに目の前の現象を簡単に検知で きるようになったら, 私は生命科学を有機化学同様に愛 すようになるのだろうか。

\section{今後の有機合成化学}

元来，実験を主体とする有機合成化学は「経験がもの をいう分野」であると筆者は思う。しかし，そのような 状況も今徐々に変化の時を迎えつつあるように感じる。 そもそもここ数年機械学習の利用, 技術の発展が著し く, そこにきて新型コロナウイルス禍でデジタルトラン スフォーメーション $(\mathrm{Dx})$ が叫ばれ, 世界中で研究の自 動化や遠隔化が進んできている。先述の通り, 反応機構 解明のような「Why」を探求する研究においてはまだし ばらくは化学者が主役であり続ける一方で, 反応条件最 適化などの「How」に焦点を当てた課題解決型研究にお いては，機械学習や自動合成の利用がますます進むよう に思っている。特に機械学習に関しては, 多くの学生さ んがこれを学ばないと将来マズいかもという追い立てら れ感をもっており, データ科学の講義を開講している大 学も多くない中で, 自分自身でテキストを購入してスキ ル向上に努めている学生さんも少なくない。筆者も頑 張って勉強しているつもりだが, 新技術獲得に本気に なった学生さんには到底かなわないと最近諦め気味であ
り, 機械学習や理論計算は筆者が学生さんに習っている 状況である。筆者としては学生さんが, 故意ではなく解 釈や方法を間違えて, 誤った報告を世に出さないよう, 注意を促したり, 専門家の先生に共同研究をお願いした りといったことをサポートできる位で,「数学が苦手で 有機合成に来たのに，いまさら機械学習は行列だとか言 われても。o」というのが本音だ。一方で, 学生さんから 色々習うのは結構良いものだと最近思っている。筆者が 学生時代にはなかなか先輩や先生から答えをそのまま教 えてもらえることはなく,「自分で考えることが最も良 い教育」という文化で育ってきた。一方で今の筆者は自 分が良いと思うことはどんどん学生に教え, 答えに近い 情報も伝えている。そうして気づいたことは, 意外と多 くの学生が筆者にも非常に有益な情報を与えてくれるこ とだ。学生さんも個々の視点で色々な情報を漁ってい て, 意外と筆者が知らない情報がもらえるので, 情報獲 得が重要な昨今, 双方の得になると思っている。

今後, 有機合成化学の研究室において合成経験の浅い 学生さんの立ち位置が変わってくるかもしれない。少な くともそのチャンスの大きい, 時代の節目に我々は立ち 会っていることは間違いないように思う。新型コロナウ イルス禍で大変な昨今だが，これをきっかけに加速がか かっている Dx は学生の皆さんが大センパイやセンセイ を差し置いて飛躍するチャンスかもしれない。学生の皆 さんには, 機会があれば, 機械学習・自動化・遠隔化あ らゆる技術を駆使して, 課題をより短時間で, より省力 的に解く試みを存分に進めてもらいたい思う。一方で, いつか, なるべく早く, 真の有機合成化学の面白みを感 じ，存分に楽しんでほしいと心から願っている。

(2021 年 1 月 12 日受理)

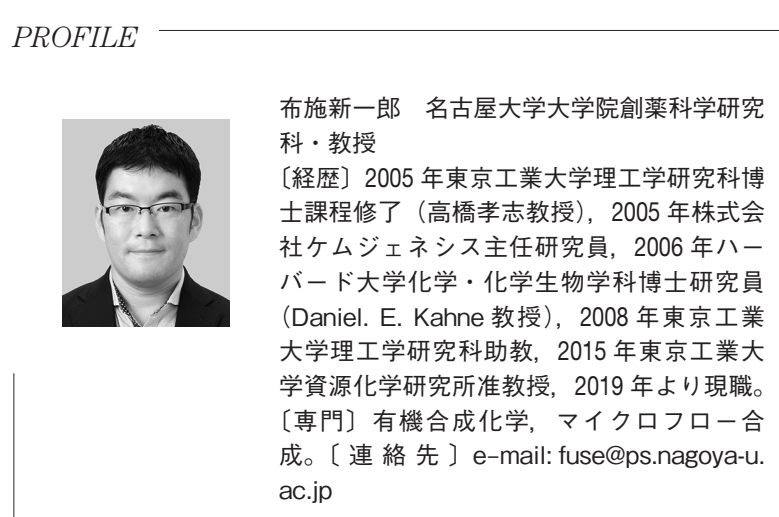

